Vol. 1 No. 2 Agustus 2021, e-ISSN : 2797-0140 | p-ISSN : 2797-0590

\title{
ANALISIS PEMANFAATAN GOOGLE CLASSROMM DI MASA PENDEMI COVID-19
}

\author{
MISNAN \\ SMA Negeri 1 Sangasanga \\ E mail : drsmisnanwibowo@gmail.com
}

\begin{abstract}
ABSTRAK
Penelitian ini menekankan pada tinjauan ulang Pemanfaatan Pembelajaran Jarak Jauh berbasis web. yang populer dengan sebutan Web-Based Education (WBE). Di mana dengan sentuhan Tehnologi Internet. Fitur yang di teliti fokusnya adalah pemanfaatan Aplikasi google classromm sebagai media pembelajaran di masa pandemic. Berbagai macam cara untuk mendapatkan hasil optimal dari pembelajaran ini di lakukan, semisal pelatihan guru dan sejenisnya. Seperti pada jenis pembelajaran jarak jauh lainnya ternyata google classromm memiliki banyak kelebihan, namun juga terdapat kekurangan. Soal biaya , umpan balik, jaringan internet, dan beberapa hal lain masih menjadi kendala pada metode pembelajaran ini.Metode yang peneliti gunakan adalah Metode Study Literatur yaitu serangkaian kegiatan yang berkenaan dengan metode pengumpulan data pustaka, membaca dan mencatat, serta mengelola bahan penelitian.
\end{abstract}

Kata Kunci : Google Classroom, Web-Based Education, Metode Pembelajaran

\section{PENDAHULUAN}

Belum reda dunia di kejutkan oleh merebaknya kasus virus yang bernama corona atau di kenal dengan istilah covid -19, kini kita di kejutkan kembali dengan munculnya varian baru dari virus corona covid-19 yang di kenal dengan varian delta . perlu di pahami bahwa varian delta merupakan strain virus corona covid -19 yang pertama kali di temukan di India. Varian Delta ini di perkirakan menyebar 40 - 60 persen lebih cepat dari pada varian Alpha yang pertama kali di temukan di Inggris. Tak lama setelah di bulan desember varian baru ini menyerang India, kita Indonesia juga di landa pandemic gelombang ke dua. Tak urung ini kembali menyebabkan di terapkannya berbagai kebijakan untuk memutus mata rantai penyebarannya yang di kenal dengan istilah PPKM darurat . Kebijakkan ini jelas berdampak negative bagi setiap aspek kehidupan termasuk di dalamnya adalah dunia pendidikan. Akibat dari kebijakkan ini banyak sekolah yang semula berencana mengadakan pembelajaran tatap muka akhirnya menunda kembali pelaksanaannya, dan kembali menggunakan pembelajaran dengan metode online atau daring (dalam Jaringan). Kondisi pandemic Cavid 19 dengan varian baru yang kian merebak membuat opsi pembelajaran online yang paling memungkinkan untuk di laksanakan.

Penggunaan Teknologi Informasi (TI) dalam pembelajaran dianggap sebagai salah satu alternatif menyikapin dalam kondisi khusus dan membawa perubahan tradisi atau budaya pembelajara serta menjadi sistem pembelajaran mandiri. Model pembelajaran yang berhubungan dengan TI dan kini menjadi perhatian dunia pendidikan adalah model pembelajaran berbasis komputer dan pembelajaran melalui media elektonik berbasis web base learning (Wena, 2009).

E-Learning merupakan sebuah proses pembelajaran berbasisi elektronik dalam penggunaannya dapat diakses online (Weni \& Isnani, 2016). Meningkatkan penguasaan terhadap materi pembelajaran, meningkatkan interaksi antara peserta didik kepada pendidik dan memudahkan pada proses pembelajaran merupakan tujuan yang dimiliki e-Learning dalam penerapannya (Darmayanti et al., 2007). Sehingga efektif digunakan dalam masa pandemi ini. Namun dalam penggunaanya kurang karena konten hanya berupa text atau slide presentasi saja, perlu adanya pengembangan untuk meningkatkan minat dalam pembelajaran (Cucus \& Aprilinda, 2016). Pengembangan e-Learning, aplikasi google classroom sebagai media pembelajaran dalam masa pandemi dinilai efektif karena penggunaannya efektif serta 
efesian dan dapat dilakukan fleksibel kapan saja dan dimana saja, praktis untuk digunakan, dan dapat meningkatkan hasil belajar (Subandi et al., 2018).

Dalam (Herliandry et al, 2020),pembelajaran online didefinisikan sebagai pengalaman transfer pengetahuan menggunakan video, audio, gambar, komunikasi teks, perangkat lunak (Basilaia \& Kvavadze, 2020) dan dengan dukungan jaringan internet (Zhu \& Liu, 2020). Infrastruktur yang mendukung pembelajaran online secara gratis melalui berbagai ruang diskusi seperti Google Classroom, Whatsapp, Kelas Cerdas, Zenius, Quipper dan Microsoft 365 (Abidah et al., 2020).

Pembelajaran e-learning dengan GC berdampak cukup efektif dalam mengembangkan interaksi dan hasil belajar siswa (Sabran \& Sabara, 2019). Soni, dkk (2018) penggunaan google classrom akan membuat pembelajaran menjadi lebih efektif terlebih lagi guru dan siswa bisa setiap saat bertatap muka melalui kelas online GC. Platform goolge classromm adalah salah satu alternative pilihan untuk menjebatani pembelajaran di masa pendemi ini.

Untuk menggunakan google classromm guru dan siswa dapat mengakses menggunakan dua cara, yaitu website dan aplikasi, untuk website dapat di akses menggunakan brower apapun seperti chrome, firefox,maupun internet explorer. Sedangkan untuk aplikasi apa di unduh secara gratis melalui aplikasi playstore untuk Android dan Appstore untuk iOS.

Namun demikian pemanfaatan google classromm sebagai media pembelajaran secara maksimal haruslah berjalan dari dua arah yaitu dari ke profesionalan guru mengoperasikan Aplikasi ini dan juga kesiapan siswa menerima model pembelajaran google classromm. Berdasar latar belakang diatas penulis mecoba untuk menggali informasi lebih dalam mengenai analisis pemanfaatan penggunaan platform Google Classroom dalam pembelajaran ditengah masa pandemi COVID-19?

\section{METODE PENELITIAN}

Studi yang dilakukan ini merupakan sebuah studi literatur (literature review) yaitu sebuah pencarian dan merangkum beberapa literatur empiris yang sesuai dan relevan dengan tema. Literatur yang digunakan berupa buku, artikel ilmiah yang berasal dari jurnal internasional maupun nasional. Literatur yang digunakan adalah literatur relevan dengan studi ini dan telah dicetak maupun dipublikasikan. Penggunaan kriteria inklusi dan eksklusi terhadap seluruh literatur merupakan metode penyeleksiannya. Tahapan dalam studi perbandingan literatur yang digunakan dalam penyusunan artikel ini mengacu pada Zed (2008) dan Khatibah (2011) Ada empat langkah yang harus dilakukan, yaitu

1) mempersiapkan peralatan untuk mengkaji: dalam bentuk pensil/ballpoint, buku catatan, dan komputer/laptop yang terhubung dengan jaringan internal;

2) menyusun bibliografi yang terplih atau sesuai (yang benar benar digunakan);

3) mengatur waktu dan fokus pada kegiatan sehingga mengurangi atau bahkan menghindari bias; dan

4) membaca dengan cermat, mencatat, dan menulis hasil.

Analisis data menggunakan paradigma analisis konten. Penyajian data menggunakan metode presentasi informal. Metode presentasi informal adalah metode penyajian data dalam bentuk formulasi dengan kata -kata/frasa reguler yang sesuai dengan aturan linguistik. Dalam menyajikan data, penulis menyertakan kutipan dari berbagai referensi yang digunakan, dalam bentuk hasil analisis, menyebutkan sumber dan diilustrasikan ber

dasarkan ringkasan atau esensi

informasi (yang bisa saja akan berbentuk parafrase berbeda namun tetap sama makna) untuk setiap topik yang dianalisis. Hal tersebut dilakukan dengan konteks pemikiran kritis dan analisis informasi secara mendalam. 


\section{HASIL DAN PEMBAHASAN}

\section{Pembelajaran di Masa Pandemi.}

Dunia sedang berjuang melawan Covid - 19, lembaga pendidikan harus cepat Antisipasi (Snelling \& Fingal, 2020), respon positif di lakukan oleh pemerintah daerah dengan berbagai kebijakkan di lapangan. Ketika peningkatan wabah corona ini dengan merebaknya kasus varian Delta atau B.1.617.2 merupakan penyakit COVID-19 yang disebabkan oleh virus Corona yang telah bermutasi. Munculnya varian virus Corona baru ini pertama kali dilaporkan di India pada Desember 2020. Varian ini telah ditemukan di lebih dari 74 negara, termasuk Indonesia. Yang penyebarannya lebih cepat dari virus corona biasa , yang bahkan masih belum terdeteksi kapan berakhirnya, memaksa beberapa pemerintah daerah membatalkan rencana pembelajaran tatap muka yang sedianya di berlakukan di awal tahun ajaran baru 2021/2022.

Selama masa pandemic covid-19 pembelajaran di rumah atau online menjadi solusi melanjutkan pembelajaran tatap muka yang sudah berlangsung. Pembelajaran online didef inisikan sebagai pengalaman transfer pengetahuan menggunakan video, audio, gambar, komunikasi teks, perangkat lunak (Basilaia \& Kvavadze, 2020) dan dengan dukungan jaringan internet (Zhu \& Liu, 2020). Ini merupakan modifikasi transfer pengetahuan melalui forum website (Basilaia \& Kvavadze, 2020) dan tren teknologi digital sebagai ciri khas dari revolusi industry 4.0 untuk menunjang pembelajaran selama masa pandemic COVID-19. Integrasi teknologi dan ragam inovasi ciri dari pembelajaran online (Banggur et al, 2018). Selain itu, yang terpenting adalah kesiapan pendidik dan peserta didik untuk berintereaksi secara online. Infrastruktur yang mendukung pembelajaran online secara gratis melalui berbagai ruang diskusi seperti Google Classroom, Whatsapp, Kelas Cerdas, Zenius, Quipper dan Microsoft (Abidah et al., 2020). Fitur Whatsapp mencakup Whatsapp Group yang dapat digunakan untuk mengirim pesan teks, gambar, video dan file dalam berbagai format kepada semua anggota (Kusuma \& Hamidah, 2020). Dengan Aplikasi Google Clasroom juga memungkinkan pendidik dan guru mengembangkan pembelajaran kreatif. Diskusi dan transfer pengetahuan secara face-to-face layaknya bertemu melalui beragam platform video teleconference yang banyak tersedia gratis seperti Zoom dan Google Meet yang tersedia di aplikasi google calssromm.Aktifitas pembelajaran mulai dari diskusi , presentasi hingga pemberian tugas, sebagian besar memang menuntut kemandirian belajar siswa .

Ini selaras dengan penelitian Firman dan Rahayu (2020) bahwa pembelajaran online melatih kemandirian belajar. Ini akan membutuhkan keterlibatan peserta didik yang lebih besar untuk meningkatkan perilaku belajar observasional. Perilaku tersebut dapat dilakukan dengan membaca, memaknai postingan diskusi dan mendiskusikan video atau konten pembelajaran (Zayapragassarazan, 2020). Ini akan membiasakan peserta didik untuk mengumpulkan dan mengelola informasi terkait tugas yang diberikan tanpa batasan ruang dan waktu. Hal ini dikarenakan pembelajaran online memungkinkan akses informasi dan pengetahuan dirumah dan dimanapun ia berada yang disesuaikan dengan kenyamanan peserta didik. Pembelajaran online yang sering juga di sebut pembelajaran daring (dalam jaringan) menuntut peran pendidik mengevaluasi efektivitas dan disesuaikan dengan kebutuhan belajar. Ini penting dilakukan untuk tetap memenuhi aspek pembelajaran seperti proses pengetahuan, moral, keterampilan, kecerdasan dan estetika (Dai \& Lin, 2020; Zhu \& Liu, 2020). Mengingat bahwa perubahan dari tatap muka ke pembelajaran online secara tidak langsung berpengaruh pada daya serap peserta d idik (Dewi,2020). Penting untuk diperhatikan yakni komunikasi orang tua dan pendidik untuk mewujudkan kemandirian belajar peserta didik selama masa pandemic COVID-19.

Melania (2020) telah melakukan survei terhadap siswa yang melakukan kegiatan pembelajaran daring. Hasil menunjukkan bahwa sebagian siswa menerima pembelajaran daring dengan alasan bahwa pembelajaran daring lebih santai, menyenangkan,fleksibel, efisien, singkat, praktis, cepat, tepat, aman, mudah, hemat waktu, 
dan hemat tenaga. Cara itu juga bisa dilakukan secara jarak jauh tanpa berkumpul di tempat yang sama. Selain itu, manfaat lain pembelajaran daring adalah orang tua bisa mengawasi anak-anaknya belajar, membuat siswa atau guru menjadi melek Tehnologi, mempercepat era 5.0, serta meningkatkan kemampuan di bidang IPTEK

\section{1) Pembelajaran berbasis web.}

Pembelajaran berbasis web yang populer dengan sebutan Web-Based Education (WBE) atau kadang disebut e-learning (electronic learning) dapat didefinisikan sebagai aplikasi teknologi web dalam dunia pembelajaran untuk sebuah proses pendidikan. Secara sederhana dapat dikatakan bahwa semua pembelajaran dilakukan dengan memanfaatkan teknologi internet dan selama proses belajar dirasakan terjadi oleh yang mengikutinya, maka kegiatan itu dapat disebut sebagai pembelajaran berbasis web.

Pembelajaran berbasis web merupakan suatu sistem untuk melaksanakan kegiatan pembelajaran jarak jauh melalui aplikasi web dan jaringan internet (Simamora, 2003).

Teknologi internet memberikan kemudahan bagi siapa saja untuk mendapatkan informasi apa saja darimana saja dan kapan saja dengan mudah dan cepat. Informasi yang tersedia diberbagai pusat data di berbagai komputer di dunia. Selama komputer-komputer tersebut saling terhubung dalam jaringan internet, dapat kita akses dari mana saja. Ini merupakan salah satu keuntungan belajar melalui internet.

a) Pandangan yang sama juga di sampaikan oleh Wena, Menurut Wena (2009) ada beberapa kelebihan dari pemanfaatan internet untuk pembelajaran berbasis web antara lain: Kelas tidak membutuhkan bentuk fisik, semuanya dapat dibangun dalam aplikasi internet.

b) Melalui internet lembaga pendidikan akan dapat lebih fokus pada program penyelenggaraan pendidikan/latihan.

c) Program WBL dapat dilaksanakan dan di- update secara cepat.

d) Dapat diciptakan interaksi yang bersifat real time (chatiing/video conference) maupun non real time (e-mail,bullletin board,mailing list).

e) Dapat diakses dari lokasi mana saja dan bersifat global.

f) Materi dapat dirancang secara multimedia dan dinamis.

g) Siswa dapat terhubung ke berbagai perpustakaan maya di seluruh dunia dan menjadikannya sebagai media penelitian dalam meningkatkan pemahaman dan bahan ajar.

Dalam pengembangan WBL lebih jauh Simamora mendeskripsikan komponenkomponen WBL, baik dalam interaksi langsung maupun interaksi tidak langsung adalah sebagai berikut : interaksi tidak langsung:

a) Surat elektronik

b) Kelompok diskusi virtual

c) Media share dokumen.

Dan untuk interaksi secara langsung antara lain: (1) Obrolan, (2) Elemen akses jarak jauh, (3) video conference.

Dari penjabaran tentang pengembangan WBL, google classroom merupakan contoh dari pembelajaran berbasis web.

\section{2) Pengertian google classromm.}

Google Classroom merupakan layanan berbasis internet yang disediakan oleh Google sebagai sebuah sistem e-learning. Google Classroom juga merupakan sebuah aplikasi yang memungkinkan terciptanya ruang kelas di dunia maya atau disebut juga kelas virtual (Hardiyana, 2015). Selain itu, Google Classroom bisa menjadi sarana distribusi tugas, submit tugas bahkan penilaian tugas-tugas yang dikumpulkan. Layanan Google Classroom di desain untuk membantu guru membuat dan membagikan tugas kepada siswa secara paperless atau tanpa menggunakan kertas sehingga ramah lingkungan. Penggunaan aplikasi ini wajib memiliki akun di Google. Google Classroom telah diperkenalkan sebagai bagian dari Google 
Apps for Education (GAFE) sejak 12 Agustus 2014. Menurut (Hakim, 2016) media ini menggunakan jaringan internet dengan menggunakan kompoter dan atau telepon seluler. Lebih lanjut Hammi mengatakan bahwa Google Classroom tersedia bagi siapa saja yang memiliki Google Apps for Education, serangkaian alat produktivitas gratis termasuk gmail, dokumen, dan drive (Hammi, 2017).

Google Classroom (Ruang Kelas Google) adalah suatu aplikasi pembelajaran secara online yang dapat digunakan oleh semua lingkup pendidikan yang membantu guru dan siswa berbagi file dalam kegiatan belajar mengajar. Guru bisa membuat kelas mereka sendiri dan membagikan kode kelas tersebut atau mengundang para siswanya. Google Classroom menggabungkan Google Drive untuk pembuatan dan distribusi penugasan, Google Docs, Sheets, Slides untuk penulisan, Gmail untuk komunikasi, Google Calendar untuk penjadwalan, dan Google Meet untuk video conference.

\section{3) Upaya optimalisasi google classromm.}

Kehadddiran platform google classromm sebagai media proses pembelajaran secara virtual. Selain itu Platform dari Google Classroom sendiri sangat membantu dalam sarana distribusi tugas, submit tugas dan penilaian yang secara langsung bias diberikan (Hammi,2017). Berbagai upaya optimalisasi pemanfaatn media ini di lakukan antara lain adalah mengadakan pelatihan pemanfaatan google classromm sebagaimana yang di lakukan oleh (Terasne dkk, 2020 ).

Secara umum dalam jurnal tersebut berisi laporan pelaksanaan pelatihan pemanfaatan goolge classromm sebagai media pembelajaran alternative pada masa pandemic Covid -19 bagi guru guru yang ada di SMP negeri 1 Peraya Barat tentang tata cara penggunaan Google Classromm. Dalam pelaksanaannya kegiatan tersebut tercantum dalam jadwal pada table berikut

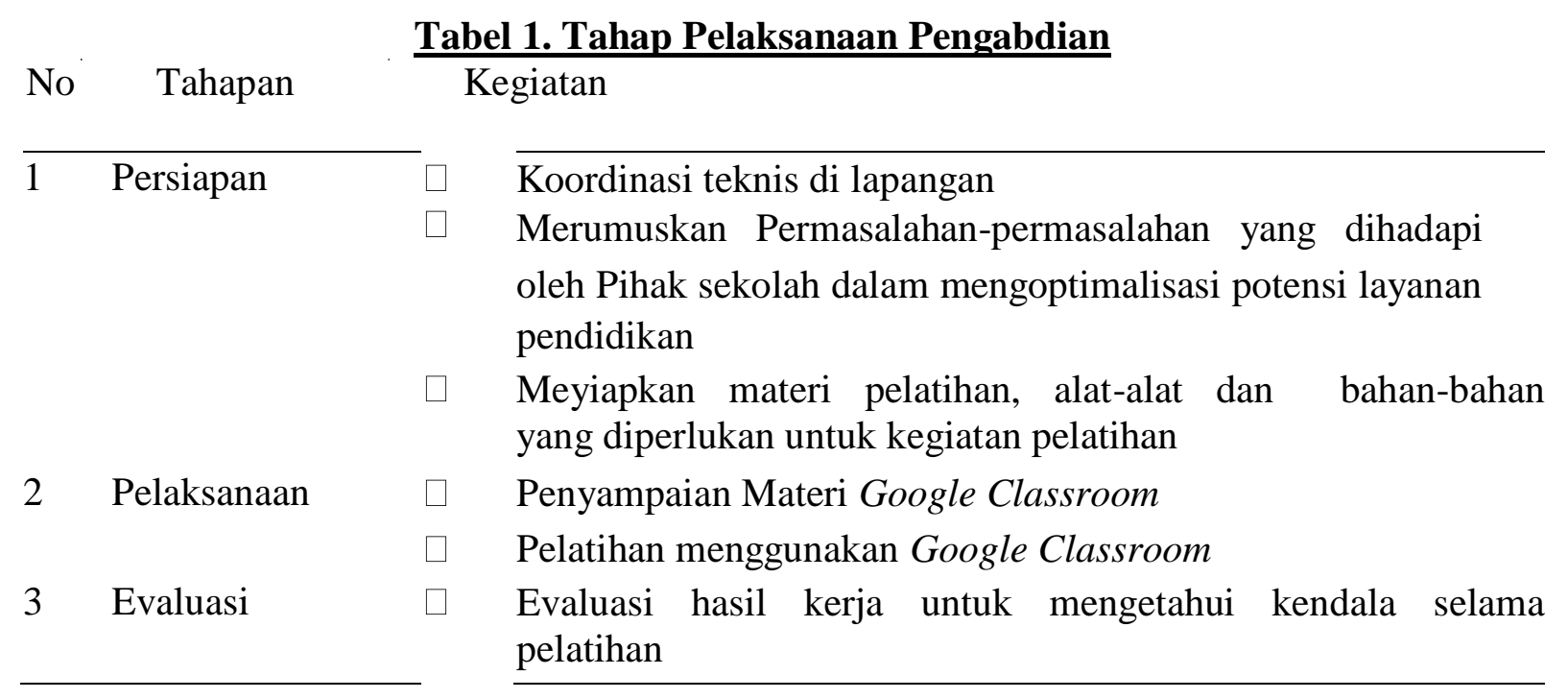
berikut.

Kegiatan-kegiatan yang dilakukan dalam implementasi program adalah sebagai

a. Memberikan pengenalan kepada guru-guru terkait Optimalisasi Pemanfaatan Google Classroom sebagai Media Pembelajaran alternatif di SMP Negeri 1 Praya Barat.

b. Peningkatkan pengetahuan dan keterampilan para guru tentang pembuatan, penggunaan serta optimaliasi pengunaan google classroom sebagai media pembelajaran alternatif melalui pemberian pelatihan berupa workshop.

Pemahaman guru tentang GC dan pemanfatan GC cukup baik setelah proses pelatihan dilakukan. Peningkatan dpaat dilihat pada tabel di bawah ini. 


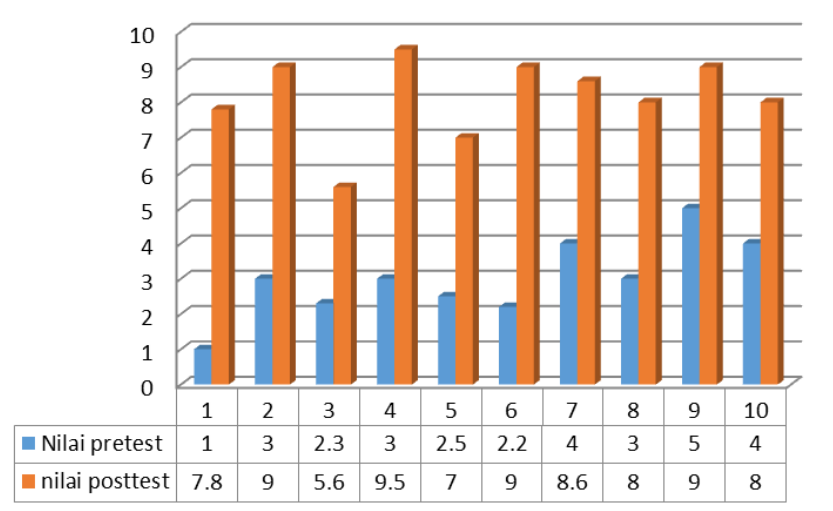

Gambar 1. Diagram peningkatan pemahaman guru tentang GC

Rata-rata peningkatan pemahaman mencapai $5.2 \%$ setelah pemberian materi tentang GC. Adanya peningkatan ini menunjukkan bahwa kegiatan pelatihan efektif.

c. Mendemonstrasikan penggunaan google classroom sebagai media pembelajaran yang telah dibuat dari hasil pelatihan.

Kegiatan terakhir dalam proses pelaksanaan pemberian materi adalah guru-guru diberikan kesempatan untuk mendemostrasikan cara menggunakan GC sebagai media alternatif. Hal ini bertujuan agar guru-guru tidak hanya memahami akan tetapi juga dapat mengaplikasikannya dengan baik. Kegiatan mendemostrasikan berjalan dengan tertib dan terlihat kemampuan guru cukup baik. Pada beberapa fitur masih perlu pendampingan secara kontinu.

Dalam laporannya di tutup dengan sebuah kesimpulan hasil pelatihan sebagai berikut :

a) Guru-guru memahami tentang e learning menggunakan Google Classromm sebagai media alternatif dalam pembelajaran dimasa pandemi Covid -19.

b) Guru-guru dapat mengunakan Google Classromm sebagai media alternatif dalam pembelajaran dimasa pandemi Covid -19 .

c) Guru dapat mendemostrasikan dengan baik cara menggunakan fitur-fitur di dalam Google Classromm.

Menurut pengamatan penulis ada yang luput dari kegiatan pelatihan tersebut yang tidak kala pentingnya dari kegiatan tersebut yaitu para guru tidak di latih untuk mempersiapkan siswanya untuk menerima google classromm sebagai media pembelajaran di masa pandemic ini. Hasil pelatihan yang hanya mengacu pada kemampuan guru memanfaatkan google classromm sebagai salah satu alternative pembelajaran di masa pandemic Covid -19, lalu bagaimana kondisi muridnya ?, ini akan terkendala apabila guru tidak di latih mempersipkan muridnya pada saat guru memakai aplikasi google classromm.

\section{4) Kelebihan dan kekurangan google classromm}

Kelebihan google classromm dapat terangkum dari kajian journal yang di tulis oleh sukmawati dengan judul " Implementasi pemanfaatan google classromm dalam proses pembelajara online di era Industri 4.0 " dalam tulisannya sukmawati memaparkan bahwa dengan menggunakan google classromm ada beberapa manfatat antara lain adalah : (1) proses pembelajaran relative lebih muda, (2) Efektif dan efisien disebabkan pendidik dapat membuat kelas, memberikan tugas, dan berkomunikasi melalui media ini (3) pengelolaan lebih baik, semua materi dapat di simpan dalam folder google classromm (4 ) terjangkau dan aman . hal senada juga di perkuat dari hasil penelitian oleh (Rini atikah dkk, 2021) dengan judul “ pemanfaatan google classromm sebagai media pembelajaran di masa pandemic cavid -19 “ dimana dari hasil penelitiannya menyatakan dengan google classromm memungkinkan kegiatan belajar mengajar menjadi lebih produktif dan bermakna dengan menyederhanakan tugas, meningkatkan kolaborasi dan membina komunikasi.selain itu google classromm juga terjangkau dan aman yang di sediakan gratis untuk sekolah, lembaga nonfit, dan perorangan serta tidak berisi iklan dan tidak pernah menggunakan konten pengguna atau data siswa untuk 
tujuan periklanan. Dalam pengamatan penulis penelitian yang di lakukan oleh sukmawati ternyata sasarannya adalah mahasisiwa yang notabennya kebanyakan sudah melek tehnologi namun untuk siswa SLTP dan SLTA tentunya tidaklah sebagaimana hasil penelitian tersebut karena selain kebanyakan gatek juga belum tentu semuanya punya fasilitas smartphone Android, namun pada penelitian (Rini Atika dkk, 2021 ) kesiapan siswa di bahas secara khusus, yang hasil wawancaranya di peroleh beragam responnya .Tidak bisa di pungkiri memang terdapat banyak masalah atau kendala yang di hadapi peserta didik pada pelaksanaan pembelajaran model ini. Seperti juga model pembelajaran online pada umumnya tentu memiliki kendala baik oleh pendidik maupun peserta didik. Kendala yang dihadapi yakni kondisi wilayah di Indonesia yang beragam menyebabkan tidak semua wilayah terjangkau oleh layanan internet dan sebaran jaringan internet yang lamban sewaktu-waktu (Khasanah et al., 2020). Ini juga memungkinkan penggunaan internet yang tinggi berpengaruh pada kesehatan peserta didik. Kendala lain yang ditemukan yakni kemampuan orang tua untuk memberikan fasilitas pendidikan online (Obiakor \& Adeniran, 2020) seperti penggunaan jaringan internet yang membutuhkan biaya (Jones \& Sharma, 2019; Purwanto et al.,2020). Hal senada juga di sampaikan oleh Attri yang menyatakan :Google classromm adalah salah satu aplikasi pembelajaran jarak jauh yang masalah dan kendalanya juga akan sama dengan model pembelajaran jarak jauh lainnya., seperti biaya , motivasi belajar , layanan, umpam balik ,kurangnya pengalaman ,serta pembiasaan ( Attri, 2012 ). pembelajaran jenis ini di nilai tidak lebih baik dari pembelajaran yang di lakukan secara langsung atau tatap muka ( Fojtik , 2018 ), hal senada juga di sampaikan oleh (Maya Mahitsa Agung Maharani,2020) melalui penelitian kulitatif diskritifnya dengan judul " Analisis situasi penggunaan google clasromm pada pembelajaran daring fisika " dalam penelitiannya di sebutkan bahwa kendala dari penggunaan google classromm antara lain adalah peserta didik kurang memahami materi yang di bagikan oleh guru , terutama materi yang berupa hitungan, banyak peserta didik yang tidak bisa mengikuti video conference karena terkendala kuota dan jaringan internet. Melalui wawancara di laporkan dari 60 responden , 59 orang menyatakan lebih senang belajar di sekolah dari pada di rumah, hanya 1 orang yang menyatakan bahwa belajar di rumah lebih menyenangkan, masalah lain yang di temukan adalah beberapa peserta didik yang tidak pernah mengisi daftar hadir dan mengumpulkan tugas. hal yang sama juga di sampaikan dalam penelitian (Rini atikah dkk, 2021) masalah biaya , motivasi belajar, serta belum meratanya jaringan internet adalah kendala yang sering di hadapi para siswa

\section{KESIMPULAN}

Berdasarkan Analisis pemahaman di atas dapat di simpulkan bahwa hampir semuanya sepakat pandemic Covid -19 telah merubah dunia pendidikan di Indonesia. Pembelajaran jarak jauh adalah alternative yang paling memungkinkan berlangsungnya pembelajaran di masa pandemic ini. Google classroom salah satu aplikasi yang banyak di pilih dalam pembelajaran berbasis online ini. Bukan tanpa pertimbangan memang fitur fiturnya menawarkan kemudahan bagi guru dan siswa. Hal ini di karenakan pembelajaran daring melalui google classromm pada kegiatan pembelajaran dapat dengan mudah di akses baik oleh guru/pendidik maupun siswa sesuai dengan kebutuhan kegiatan pembelajaran . Optimalisasi pemanfaatan google classromm sebagai media pembelajaran alternative di masa pandemic Covid -19 dapat dilakukan dengan berbagai cara misalnya melalui pelatihan guru , namun demikian mempersiapkan siswa untuk menerima aplikasi ini dalam pembelajaran adalah hal lain yang tidak boleh luput dari tujuan suksesnya pembelajaran model ini. Peran guru dalam mengevaluasi efektifitas pembelajaran daring ini sangatlah penting, hal ini di karenakan perubahan dari pembelajaran tatap muka ke bentuk pembelajaran online secara tidak langsung berpengaruh pada daya serap peserta didik dan di perlukan kerja sama dengan orang tua / wali murid untuk meningkatkan taraf keberhasilannya. 
Abidah, A, dkk. (2020). The Impact of Covid-19 to Indonesian Education and Its Relation to the Philosophy of "Merdeka Belajar" Studies in Philosophy of science and Education (SiPoSE).,1 (1), 38-49

Attri, A. K. (2012). Distance Education: Problems And Solutions. International Journal Of Behavioral Social And Movement Sciences, 1(4), 42-58.

Banggur, M. D. V., Situmorang, R., \& Rusmono. (2018). Pengembangan Pembelajaran Berbasis Blended Learning pada Mata Pelajaran Etimologi Multimedia. JTP-Jurnal Teknologi Pendidikan, 20(2), 152-165. https://doi.org/10.21009/JTP2002.5

Cucu,A. , dan Aprilinda. Y (2016). Pengembangan E-Learning Berbasis Multi Media Untuk Efektifitas Pembelajaran Jarak Jauh. Jurnal Sistem Informasi Dan Telematika,7(1),1 5

Dai, D., \& Lin, G. (2020). Online Home Study Plan for Postponed 2020 Spring Semester during the COVID-19 Epidemic: A Case Study of Tangquan Middle School in Nanjing, Jiangsu Province, China. SSRN Electronic Journal. https://doi.org/10.2139/ssrn.3555539

Dewi, W. A. F. (2020). Dampak Covid-19 Terhadap Implementasi Pembelajaran Daring di Indonesia. 2(1), 55-61.

Darmayanti, T.,setiani, M.Y.,\& Oetoyo, B. ( 2007). E- Learning Pada Pendidikan Jarak Jauh : Konsep yang Mengubah Metode Pembelajaran I Perguruan Tinggi Di Indonesia. Jurnal Pendidikan terbuka dan Jarak Jauh, 8(2). 99-133

Program Studi Sarjana Pendidikan Matematika, Universitas Singa perbangsa Karawang, Indonesia

Firman, \& Rahayu, S. (2020). Pembelajaran Online di Tengah Pandemi Covid-19. Indonesian Journal of Educational Science (IJES), 2(2), 81-89. https://doi.org/10.31605/ijes.v2i2.659

Fojtík, R. (2018). Problems of Distance Education. International Journal of Information and Communication Technologies in Education, 7(1), 14-23.

Hakim, A.B., (2016). Efektifitas Penggunaan E-Learning Moodle, Google Classroom Dan Edmodo. I-STATEMENT: Information System and Technology Management, 2(1).

Hammi, Z. (2017). Implementasi Google Classroom Pada Kelas XI IPA MAN 2 Kudus.87

Hardiyana, Andri. (2015). Implementasi Google Classroom sebagai Alternatif dalam Meningkatkan Mutu Pembelajaran di Sekolah. Karya Tulis Ilmiah, Cirebon :SMA Negeri 1 Losari.

Herliandry, L. D., Nurhasana, N., Suban, M.E.,\& Kuswanto, H. (2020). Pembelajaran Pada Masa Pandemi Cavid - 19. JTP-Jurnal Tehnologi Pendidikan, 22(1), 65 -70

Jones, K., \& Sharma, R. (2019). Reimagining A Future For Online Learning.

Khasanah, D. R. A. U., Pramudibyanto, H., \&Widuroyekti, B. (2020). Pendidikan Dalam Masa Pandemi Covid-19. Jurnal Sinestesia, 10(1), 41-48.

Khatibah. (2011). Penelitian kepustakaan. Iqra': Jurnal Perpustakaan dan Informasi, 05 (01). pp. 36-39

Kusuma, J. W., \& Hamidah. (2020). Platform Whatsapp Group Dan Webinar Zoom Dalam Pembelajaran Jarak Jauh Pada Masa Pandemik Covid 19. Jurnal Ilmiah Pendidikan Matematika Volume, 5(1).

Maya Mahista Agung Mahardini. (2020). Analisis Situasi Penggunaan Google Clasromm Pada Pembelajaran Daring Fisik . Jurnal Pendidikan Fisika Universitas Muhammadiyah Metro 5(2), 219 - 220

Mestika Zed. (2008). Metode Penelitian Kepustakaan . Jakarta : Yayasan Pustaka Obor Indonesia .

M. Wena. (2009). Stategi Pembelajaran Inovatif Kontemporer. Jakarta : Bumi Aksara.

Obiakor, T., \& Adeniran, A. (2020). Covid-19: Impending Situation Threatens To Deepen 
Nigeria' S Education Crisis. Center For The Study Of The Economies Of Africa.

Purwanto, A., Pramono, R., Asbari, M., Santoso, P. B., Wijayanti, L. M., Hyun, C. C., \& Putri, R. S. (2020). Studi Eksploratif Dampak Pandemi COVID-19 Terhadap Proses Pembelajaran Online di Sekolah Dasar. Journal of Education, Psychology, and Counseling, 2, 1-12.

Rini Atika, Rani Titik Prihatin, Herni Hermayanti, Jajang Misbah (2021), Pemanfaatan Google Classromm Sebagai Media Pembelajaran Di Masa Pendemi Cavid-19. Jurnal PETIK. 9 (2) : $15-16$

Sabran \& Sabara E. (2019). Keefektifan Google Classroom Sebagai Media Pembelajaran. Prosiding Seminar Nasional Lembaga Penelitian Universitas Negeri Makassar "Diseminasi Hasil Penelitian melalui Optimalisasi Sinta dan Hak Kekayaan Intelektual” ISBN : 978-602-5554-71-1

Simamora, L. (2003). E-learning: Konsep dan Perkembangan Teknologi yang Mendukungnya., Cakrawala Pendidikan, E-learning dalam Pendidikan. Jakarta: Universitas Terbuka

Soni, dkk. (2019). Optimalisasi Pemanfaatan Google Classroom Sebagai Media Pembelajaran DI SMK Negeri 1 Bangkinang. Jurnal Pengabdian Untuk Mu Negeri, Vol.2 No.1.

Subandi, S., Choirudin, C., Mahmudi, M., \& Nizaruddin, N. (2018). Building Interactive Communication with Google Classroom. International Journal of Engineering \& Technology, 7(2.13), 460-463

Terasne, Salim,A., Permana D., Sugianto. N., Suryati, Arif. M.,\& Putri. K.H.R., (2019)

Pelatihan Pembuatan Video Pembelajaran bagi Guru SMA Hang Tuah 3 Mataram, Jurnal Lumbung Inovasi: Jurnal Pengabdian Pada Masyarakat. 4 (1). 77-81.

Weni. D. M,. \& Isnani, G ( 2016 ). Meningkatkan Hasil Belajar Siswa dengan Pengembangan Media Pembelajaran . jurnal pendidikan bisnis dan Manajemen 2(2). 144 - 127

Zayapragassarazan, Z. (2020). COVID-19: Strategies for Online Engagement of Remote Learners. 246, 1-11.

Zhu, X., \& Liu, J. (2020). Education in and After Covid-19 : Immediate Responses and LongTerm Visions 